\title{
SPOP wt Allele
}

National Cancer Institute

\section{Source}

National Cancer Institute. SPOP wt Allele. NCI Thesaurus. Code C102537.

Human SPOP wild-type allele is located in the vicinity of $17 q 21.33$ and is approximately 79

$\mathrm{kb}$ in length. This allele, which encodes speckle-type $\mathrm{POZ}$ protein, may play a role in the regulation of both protein ubiquitination and transcriptional repression. 